\title{
Expression, modification, and localization of the fushi tarazu protein in Drosophila embryos
}

\author{
Henry M. Krause, ${ }^{1}$ Roman Klemenz, ${ }^{2}$ and Walter J. Gehring ${ }^{3}$ \\ Department of Cell Biology, Biozentrum, University of Basel, CH-4056 Basel, Switzerland
}

The fushi tarazu (ftz) protein of Drosophila is required during embryogenesis for the process of body segmentation. To study the biochemical properties of the $f t z$ protein, $f t z$ cDNA was expressed in Escherichia coli and the protein was purified to homogeneity. Polyclonal antibodies raised against the purified protein were used to localize and quantitate the protein during embryogenesis. Three temporally and spatially distinct phases of expression were observed, which include a previously undetected period later in embryogenesis. During this last phase, the protein is localized predominantly in the developing hindgut. Analysis of embryonic ftz protein on Western blots permitted us to approximate the number of protein molecules per nucleus. During the blastoderm phase of development, when $\mathrm{ftz}$ protein is most abundant, we estimate that there are $\sim 20,000$ molecules of protein per $\mathrm{ftz}$-expressing nucleus. The embryonic $\mathrm{ftz}$ protein migrates more slowly on SDSpolyacrylamide gels than protein made either in $E$. coli or in a reticulocyte lysate system in vitro, indicating that it is modified in the embryo. To facilitate characterization of $f t z$ protein made in embryos, an $f t z$ overexpression system functional in Drosophila was developed. When fused to an $h s p 70$ heat shock promoter and introduced into the germ line by P-element-mediated transformation, ftz could be overexpressed at all stages of development by heat shock. This protein is localized in the nucleus and comigrates on SDSpolyacrylamide gels with endogenous $f t z$ protein. Two-dimensional gel electrophoresis followed by Western blotting resolves the overexpressed protein into a series of isoforms that differ in charge and electrophoretic mobility. Post-translational modification may influence the biochemical properties and functions of the ftz protein during embryogenesis.

[Key Words: ftz protein; expression; localization; modification; quantitation]

Received January 4, 1988; revised version accepted June 13, 1988.

An intriguing aspect of Drosophila embryogenesis is the process of body segmentation. In this process, the embryo is divided into repeating units that eventually adopt unique identities and functions (for reviews, see Gehring and Hiromi 1986; Scott and O'Farrell 1986). The fushi tarazu (ftz) gene was first identified through its requirement in this metamerization process (Wakimoto and Kaufman 1981; Wakimoto et al. 1984). Embryos that contain a homozygous deletion of the $f t z$ gene produce only half the normal number of body segments and die before hatching as larvae. Because only certain regions of every other segment are deleted, $f t z$ was classified as one of the 'pair-rule' class of segmentation genes. The gene is located within a cluster of homeotic genes that comprise the Antennapedia Complex (Wakimoto and Kaufman 1981). The gene has since been cloned (Kuroiwa et al. 1984; Weiner et al. 1984) and se-

Present addresses: 'Banting and Best Institute for Medical Research, $\mathbf{C H}$ Best Institute, University of Toronto, Toronto, Ontario M5G 1L6, Canada; ${ }^{2} L u d w i g$ Krebsforschungsinstitut, Inselspital, CH-3010 Bern, Switzerland.

${ }^{3}$ Corresponding author. quenced (Laughon and Scott 1984; A. Kuroiwa, S. Baumgartner, and W.J. Gehring, unpubl.).

Transcription of the $f t z$ gene is detectable only during embryogenesis (Kuroiwa et al. 1984; Weiner et al. 1984). The message can be detected on Northern blots between the second and tenth hours of embryogenesis. During the first of two peaks in expression, the transcripts have been shown by in situ hybridization to accumulate in seven transverse bands that encircle the embryo (Hafen et al. 1984). These bands correspond in location to the regions that are deleted in $f t z^{-}$embryos. Immunolocalization of the protein product shows that it accumulates in the nucleus (Carroll and Scott 1985). Immunostaining of older embryos also demonstrated the occurrence of a second phase of $\mathrm{ftz}$ expression localized to the developing nervous system (Carroll and Scott 1985). The use of $f t z$ promoter sequence fusions to the reporter gene $\beta$ galactosidase also shows that the gene is expressed in both locations and that the temporal and spatial regulation lies predominantly at the level of transcript initiation (Hiromi et al. 1985; Hiromi and Gehring 1987). It has been demonstrated recently that $f t z$ expression in the nervous system is required for the expression of 
other genes and for the specification of certain cell neuronal lineages (Doe et al. 1988).

The first insight into the molecular mechanisms by which homeotic and segmentation genes control aspects of pattern formation came when the sequences of these genes were compared. It was found that the $f t z$ gene has a 180-bp region of homology to homeotic genes found in the Antennapedia and Bithorax complexes (McGinnis et al. 1984a,b; Scott and Weiner 1984; Shepherd et al. 1984), which determines the identities of the anterior and posterior segments of the fly, respectively. This sequence, now known as the homeo box, encodes a 60amino-acid peptide called the homeo domain. A portion of the homeo domain bears homology to the yeast developmental control genes Mata1 and Mata2 and the helixturn-helix motif of a number of prokaryotic regulatory proteins, which enables them to bind DNA in a sequence-specific manner (Laughon and Scott 1984; Shepherd et al. 1984). A few homeo-domain-containing proteins have been shown to bind DNA with some sequence specificity (Desplan et al. 1985; Fainsod et al. 1986). Recently, Hall and Johnson (1987) have also demonstrated that the yeast protein Mat $\alpha 2$ binds to specific DNA sequences in a homeo-domain-dependent manner. These results and the nuclear localization of these proteins suggest that they control aspects of pattern formation in Drosophila through an ability to bind to specific DNA sequences.

Although much is known about the temporal and spatial expression of the $f t z$ gene, little is known about the actual properties and roles of the protein. Some of those properties are described here. Full-length protein expressed in Eschericha coli was purified and used to generate antibodies. Immunostaining of embryos using these antibodies confirms the data of Carroll and Scott (1985) and, in addition, shows that $f t z$ protein is expressed a third time during a later stage of embryogenesis. It is also shown that $f t z$ protein produced in Drosophila has a number of properties that are different from protein synthesized in two heterologous systems. Overexpression of $f t z$ protein in Drosophila allowed us to characterize the protein and show that it is heavily modified.

\section{Results}

\section{Expression of $\mathrm{ftz}$ in heterologous systems}

To facilitate our biochemical characterization of the $f t z$ protein, we first attempted to express the protein in bacteria as a means of producing large quantities of protein rapidly and economically. A cloning scheme was chosen that would produce the same protein as expected in Drosophila embryos, except for two additional amino acids encoded at the amino-terminal end. Two wellcharacterized expression systems were used initially in our attempt to express the gene in bacteria, and both failed to produce plasmid-specific expression of protein. In a third expression system, which has been described recently by Studier and Moffatt (1986), expression of a protein with an apparent molecular weight of 63,000 was induced (Fig. 1B, cf. lanes 1 and 2). The expression plasmid that we constructed, pGEMF1, was made by subcloning a $f t z$ cDNA restriction fragment from one of the nonexpressing vectors into the plasmid pGEM-1 (Promega Biotec) such that the $f t z$ gene is under the control of pGEM-1 T7 promoter (see Fig. 1A). Induction is achieved either by infecting cells that contain the plasmid with $\lambda$ phages, which carry T7 RNA polymerase gene, or, alternatively, by using a lysogenic cell line that harbors a T7 RNA polymerase gene under the control of an inducible lac promoter.

The $63-\mathrm{kD}$ protein induced by isopropanol- $\beta$-D-thiogalactopyranoside (IPTG) in pGEMF 1-transformed cells comigrates with protein translated in vitro using RNA transcribed from any of the $f t z$ expression vectors constructed previously (Fig. 2, lanes 1 and 2). The reason that all expression systems were functional in vitro and that only the T7 system produced detectable levels of protein in bacterial cells (by either Coomassie blue staining or $\left[{ }^{35} \mathrm{~S}\right]$ methionine labeling was not pursued; however, a number of potential advantages have been described by the developers of the system (see Studier and Moffatt 1986). Even with these advantages, however, $f t z$ protein only accumulated to a maximum abundance of $3-5 \%$ of total cellular protein, a value significantly lower than values of $30-50 \%$ reported for other proteins in this system (Studier and Moffatt 1986). Inspection of Western blots shows that induced cells contain much degraded $f t z$ protein, suggesting that proteolysis may play a major role in limiting the abundance of the protein in the cell (data not shown).

Because the molecular weight of the $f t z$ protein predicted by the sequence of the coding region is $47.5 \mathrm{kD}$, and the induced protein migrates on SDS-polyacrylamide gels as a $63-\mathrm{kD}$ protein, we examined the pGEMF1 plasmid carefully for cloning errors. Restriction analysis, DNA sequencing, and in vitro translation of runoff transcripts (data not shown) showed that the mobility of the protein as a $63-\mathrm{kD}$ polypeptide on SDSPAGE appears to be an inherent property of the protein. Indeed, several homeotic and segmentation proteins have also been observed to migrate anomalously on SDS-polyacrylamide gels (Carroll and Scott 1985; Ollo and Maniatis 1987; U. Walldorf, P. LeMotte, and B. Dalle Carbonare, unpubl.).

Having achieved overexpression of the $f t z$ protein in $E$. coli, we proceeded to work out a purification procedure. Lysis of the cells by sonication, french pressing, or treatment with detergent, followed by centrifugation consistently pelleted essentially $100 \%$ of the induced $f t z$ protein (Fig. 1B, lane 3). The protein could not be solubilized by decreasing the amount of protein made in the cell or the rate of protein synthesis. Adding nonionic detergents and varying the $\mathrm{pH}$ and ion composition of the lysate also failed to solubilize the protein. Only treatment with denaturing levels of urea or guanidium hydrochloride proved successful, although complete removal of these reagents by dialysis again resulted in precipitation of the protein. Similarly, $>50 \%$ of the protein produced in a reticulocyte lysate in vitro was also pre- 

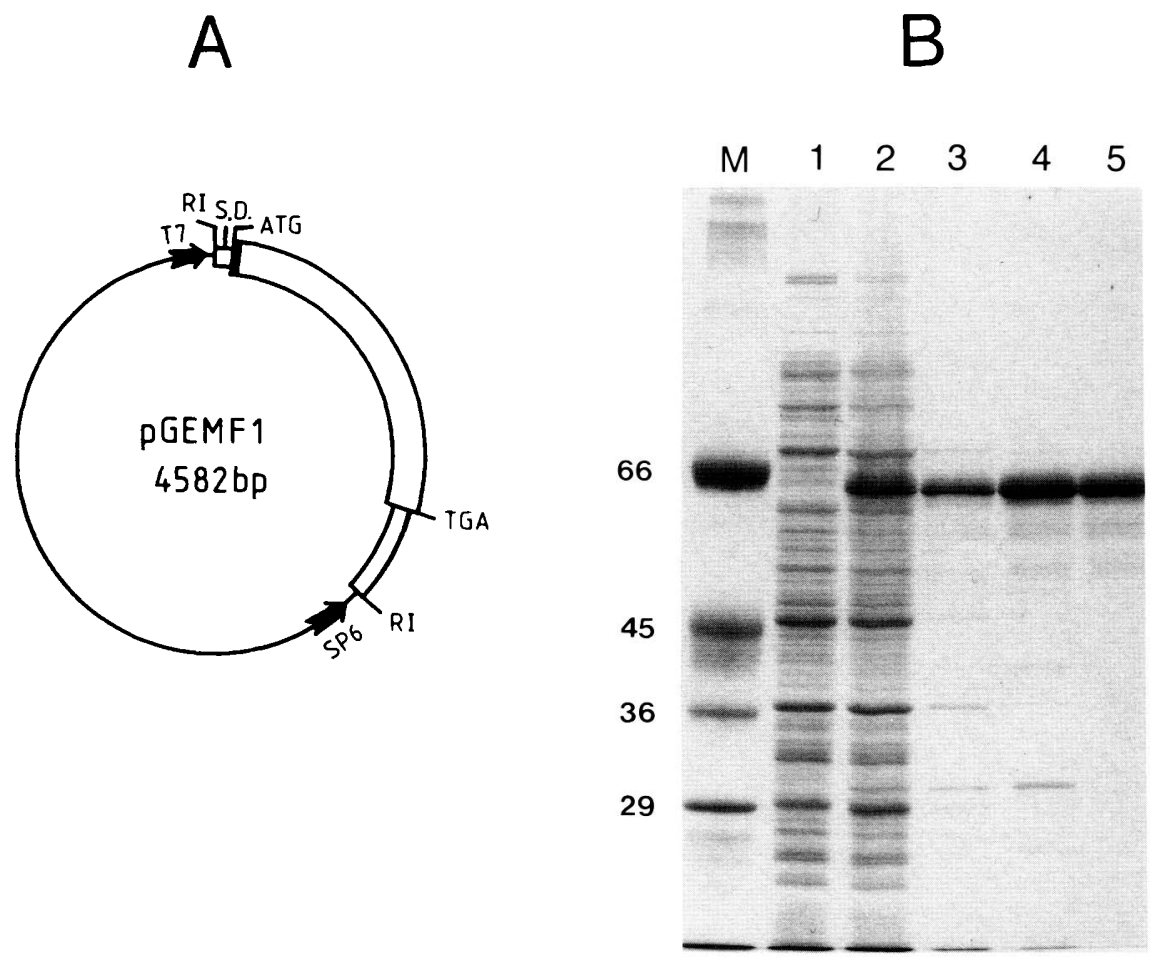

Figure 1. Expression and purification of $f t z$ protein in E. coli. $(A)$ The $f t z$ expression plasmid pGEMFl contains $f t z \mathrm{cDNA}$ under the transcriptional control of the T7 phage promoter (arrow). Transcription is achieved in an $E$. coli lysogen by inducing expression of an endogenous T7 polymerase gene. A short sequence between the T7 promoter and the $f t z$-coding region contains a strong T5 phage Shine-Dalgarno sequence (S.D.) and three codons for Met, Arg, and Asp, which replace the Met codon of the normal $\mathrm{ftz}$ gene. Thus, the encoded protein differs from the actual $f t z$ protein by only two amino acids. $(B)$ SDS-gel electrophoresis of samples prepared during $f t z$ protein purification show uninduced cells (1), cells induced with IPTG for $2 \mathrm{hr}$ (2), the cellular lysate pellet (3), protein after washes and solubilization (4), and purified protein eluted from a double-stranded DNA cellulose column (5). Molecular weight marker sizes are indicated to the left $(M)$.

cipitated by centrifugation (data not shown). Solubility problems have also been reported for $f t z$ and engrailed fusion proteins (Carroll and Scott 1985; Desplan et al. $1985)$ and Krüppel protein expressed in tissue culture cells (Ollo and Maniatis 1987). Therefore, it was decided to use this property to advantage by washing the lysate pellet first in high salt and then detergent, before solubilization in deionized $6 \mathrm{M}$ urea (Fig. 1B, lane 4). The solubilized protein was then passed over a DEAE column to remove nucleic acids, dialyzed against a $2 \mathrm{M}$ urea-containing buffer, and loaded on a double-stranded DNA cellulose column. The bound protein eluted from the column in $2 \mathrm{M}$ urea between 175 and $225 \mathrm{~mm} \mathrm{NaCl}$, indicating that it possesses general binding affinity for DNA. At this point, the protein was essentially pure, as determined by Coomassie blue staining of SDS-polyacrylamide gels. Other than $f t z$ protein, only a few of the high-molecular-weight $f t z$ degradation products can be seen (Fig. 1B, lane 5). This purification procedure yields $\sim 20 \mathrm{mg}$ of essentially pure protein from a liter of induced cells and can be completed in a single day when starting with frozen cells.

The $f t z$ protein isolated by this procedure is also capable of binding DNA in a sequence-specific manner
(Krause and Genring 1988, and unpubl.). However, the protein tends to aggregate on the DNA template and exhibits low specific to nonspecific ratios of DNA-binding affinities. The problem of protein solubility, taken together with these observations, suggests that processes or components of the cells in which the protein is normally expressed may be required to solubilize the protein and possibly enhance the selectivity of specific DNA binding. To explore this possibility, we set out to identify $f t z$ protein extracted from Drosophila embryos and to compare its properties with those of the protein isolated from $E$. coli.

\section{Detection and quantitation of $\mathrm{ftz}$ protein synthesized in Drosophila}

The production of antibodies directed against $f t z$ protein was a prerequisite in performing the experiments that follow. Antibody production was made possible by the expression of $f t z$ in $E$. coli. The $f t z$ protein, purified as described, was injected into rabbits in the presence of 2 $M$ urea. As shown in Figure 2, Western blot analysis of $f t z$ protein expressed in $E$. coli shows that the antibodies bind specifically to the $63-\mathrm{kD} \mathrm{ftz}$ protein band (Fig. 2, 


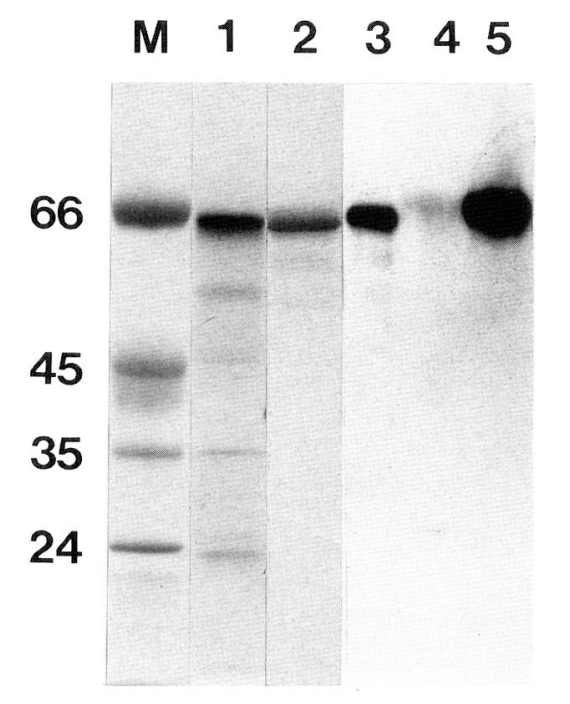

Figure 2. Comparison of protein synthesized in Drosophila and in heterologous systems. Samples containing $f t z$ protein were resolved on a $12 \%$ SDS-polyacrylamide gel and represent ${ }^{35} \mathrm{~S}$-labeled $f t z$ protein transcribed in vitro from the pGEMF1 plasmid and translated in a reticulocyte lysate (1), Coomassiestained $f t z$ protein purified from $E$. coli $(2) f t z$ protein purified from $E$. coli detected by immunoblotting (3), ftz protein from 3to 4-hr-old embryos detected by immunoblotting (4), and $f t z$ protein overexpressed by heat-shocking AAl embryos carrying pHSftz, also detected by immunoblotting (5). Protein samples in lanes $M, 1$, and 2 were run on the same gel; those in lanes 3, 4 , and 5 were run on a different gel.

lane 3). To see whether the antibodies were also capable of recognizing the Drosophila protein, embryos that were $3-4 \mathrm{hr}$ of age were homogenized in loading buffer and loaded directly on an SDS-polyacrylamide gel. After transfer to nitrocellulose, $f t z$ protein was detected by immunostaining. A weak fuzzy band that migrates somewhat slower than the purified $E$. coli protein was detected (Fig. 2, lane 4). The ability to detect the Drosophila ftz protein by immunoblotting proved to be crucial in permitting the comparisons of protein synthesized in different systems. That this band corresponds to the embryonic $f t z$ protein will be shown more conclusively later in this paper.

One of the advantages of immunoblotting is that it allows quantitation of the protein that is detected. The $f t z$ protein identified in lane 4 of Figure 2 was generated during the period of embryogenesis when it is most abundant (see below). By cutting out and counting the ${ }^{125}$ I-labeled band (see Methods) and comparing the value to those generated by known amounts of purified $E$. coli protein, a rough estimation of its abundance could be made. Because the transfer of proteins to nitrocellulose was complete (as determined by Coomassie blue staining), polyclonal antibodies were added in excess, and the antigens detected were denatured, this comparison should be valid. It is possible, however, that pro- teins present in the extracts or that modifications covalently bound to the $f t z$ protein might reduce the number of antibody molecules bound per molecule of antigen. If we assume, however, that both the E. coli and Drosophila proteins are recognized with equal affinity, the amount of Drosophila $\mathrm{ftz}$ protein present in lane 4 of Figure 2 is $\sim 1.1 \mathrm{ng}$. Knowing that this amount was derived from $\sim 4 \mathrm{mg}$ (wet weight), or 320 embryos, with each embryo possessing $\sim 2100$ nuclei that express $f t z$ protein $(-35 \%$ of 6000 blastoderm nuclei), we estimate the number of $f t z$ protein molecules per nucleus to be $\sim 20,000$. Assuming that the volume of a blastoderm nucleus is $\sim 1.5 \times 10^{-13}$ liters /using the dimensions $4.5 \times 12.5 \mu \mathrm{m}$ and averaging the calculated volumes for a rotational ellipsoid and a cylinder) and provided that the distribution of protein within a nucleus is uniform, 20,000 molecules would correspond to a concentration of $\sim 2 \times 10^{-7} \mathrm{M}$.

The Western blots show that the $f t z$ antibodies have a high specificity and affinity for the $f t z$ protein $10.1 \mathrm{ng}$ of $f t z$ protein is detectable). However, the levels of protein expressed during embryogenesis are very close to the threshold of detectability. The quantitation described above also indicates that $4 \mathrm{~kg}$, or $3 \times 10^{8}$, of 3 - to 4 -hrold embryos would be required to yield a maximum of 1 $\mathrm{mg}$ of $f t z$ protein. Considering the short half-life of the protein in intact cells $(\sim 6 \mathrm{~min}$; Edgar et al. 1986), this makes purification to homogeneity a daunting task.

\section{Overexpression of $\mathrm{ftz}$ in Drosophila embryos}

To facilitate the isolation and characterization of $f t z$ protein made in Drosophila embryos, we attempted to construct an expression vector that would make it possible to overexpress the protein in all tissues and at all times during embryogenesis. This was accomplished by placing a genomic DNA fragment containing the $f t z$ gene under the control of an hsp 70 heat shock promoter (see Fig. 3A) in the P-element vector pHT4 (Schneuwly et al. 1987). The resulting plasmid pHSftz could then be transformed stably into flies using P-element-mediated germ-line transformation (Rubin and Spradling 1982). Eight stable fly lines were derived from injections with the pHSftz P-element construct: AA1, AA9, AA12, $\mathrm{AA} 17$, and AA22 are third chromosome insertions, whereas lines AA3, AA19, and AA24 are second chromosome insertions. In the stocks $\mathrm{AA} 3, \mathrm{AA} 12$, and AA19, pHSftz insertions are homozygous lethal and are therefore maintained as balanced stocks.

Transformants were tested for heat shock-dependent $f t z$ expression by three different assays. In the first assay, SDS-gel electrophoresis of extracts from heat-shocked embryos representing each transformant line was performed and analyzed by immunoblotting to detect $f t z$ protein. In each case, a band was observed corresponding to the band detected in 3- to 4- or 8- to 10-hr-old wildtype embryos (see, e.g. Fig. 2, lane 5). Only background levels of protein were detected in non-heat-shocked embryos and in heat-shocked wild-type embryos (data not shown). The amount of $f t z$ protein produced upon heat 

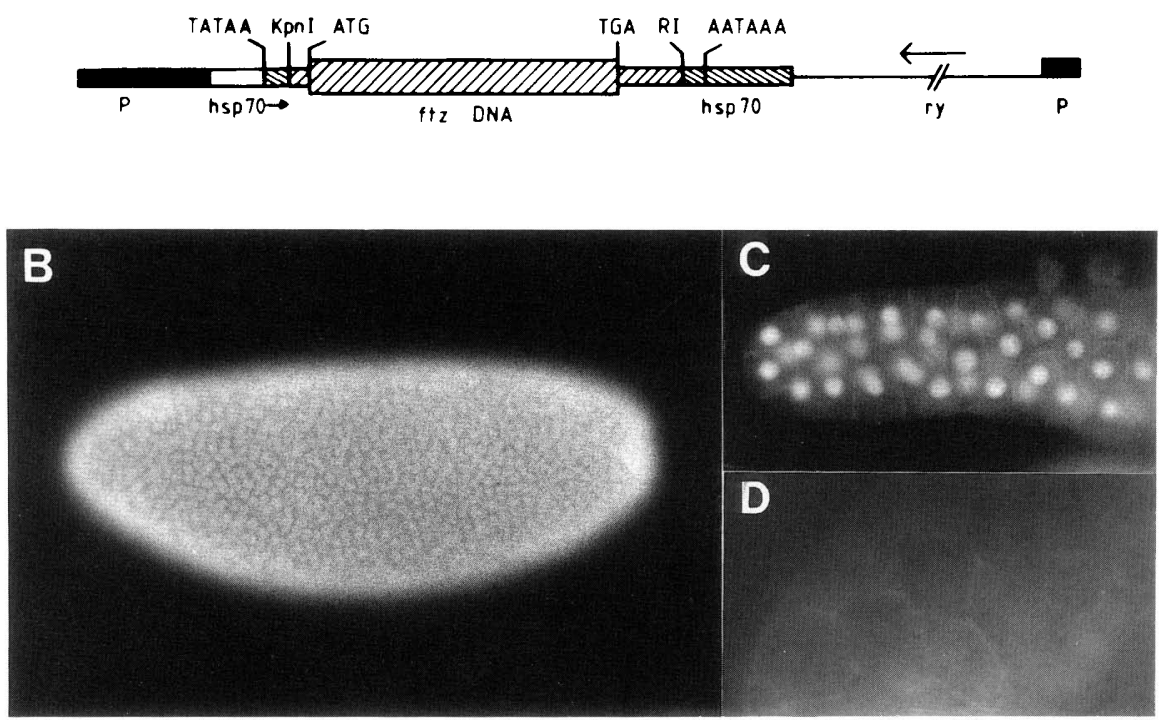

Figure 3. $f t z$ overexpression in Drosophila. $(A)$ The P-element vector, pHS $f t z$, contains a promotor fusion of the hsp 70 promoter, and a genomic $f t z$ DNA fragment that includes $\sim 100 \mathrm{bp}$ of leader and $420 \mathrm{bp}$ of $f t z$ trailer DNA [from the KpnI to EcoRI (RI) sites]. $f t z$ DNA is flanked by hsp70 leader and trailer DNA (hatched in opposite direction), and hsp70 DNA, in turn, is flanked by P-element vector DNA (solid black regions). The rosy gene (ry) serves as a positive marker for fly transformation. (B) Expression of pHSftz in a blastoderm AAl embryo. Anterior is to the left and dorsal is up. Two- to three-hour-old embryos were heat-shocked for $15 \mathrm{~min}$ at $37^{\circ} \mathrm{C}$ and fixed after a 15 -min recovery at room temperature. $f t z$ protein was detected in whole embryos using $f t z$ antibodies and fluoresceinconjugated anti-rabbit secondary antibodies. Staining is uniform and predominantly nuclear. $(C)$ pHS $f z$ induction in larvae. Because immunolocalization is not possible on whole larvae, a salivary gland dissected from a heat-shocked third instar larva is shown. $f t z$ protein detected by immunofluorescence is also nuclear. $(D)$ Immunofluorescent staining of a salivary gland from a heat-shocked AAl larva (as in $C)$ using preimmune serum at the same dilution as in $C(1: 50)$. The weak immunofluorescent signal seen in cellular membranes in $C$ is also visible here. The magnification used is two times that of $C$.

shock varied approximately twofold between different transformant lines. Maximal expression of $f t z$ protein was achieved by heat-shocking at $37^{\circ} \mathrm{C}$ for $3 \mathrm{hr}$. It was also found that, by body weight, embryos produced about twice as much $f t z$ protein as third instar larvae and contained fewer proteolytic degradation products. Under optimal conditions, AAl produced $f t z$ protein in a 20- to 40-fold excess over levels produced in wild-type 3to 4-hr-old embryos (cf. lanes 4 and 5). Similar values were also found using embryos derived from the heat shock $f t z$ transformant $h s f 2$ (Struhl 1985). These levels of accumulation are far below those of heat shock proteins produced under similar conditions and suggest that there are processes that limit the expression or accumulation of $f t z$ protein and/or transcripts.

To examine the localization of protein expression, heat-shocked embryos and larvae were also analyzed by immunofluorescence. Usually, protein was detected uniformly in all nuclei and in all tissues, although the intensity of staining sometimes varied within and between individuals after longer heat shocks. This may have been due to the method of heat shock and/or the detrimental effects of heat or excess $f t z$ protein on different individuals. Figure 3B shows the typical uniform distribution of $f t z$ protein in a blastoderm embryo. Uniform distribution was also observed in heat-shocked hsf2 embryos obtained from Gary Struhl (Struhl 1985). The embryo shown in Figure 3B was heat-shocked for 15 min at $37^{\circ} \mathrm{C}$ and fixed after a 15 -min recovery; it should therefore be representative of embryos that produced the reciprocal $\mathrm{ftz}$ phenotype described by Struhl (1985). Figure $3 \mathrm{C}$ shows the nuclear staining of $f t z$ protein in a salivary gland dissected from a heat-shocked third instar larva. Because some background staining of the salivary gland cellular membranes was detected, immunostaining was also performed with preimmune serum (Fig. 3D). This also shows some staining of the cellular membranes, indicating that the background detected is recognized by antibodies that were already present in the rabbit before it was injected with $f t z$ protein. This staining was not detected with the higher dilutions of serum that were used in subsequent experiments.

Having ascertained that all pHSftz-transformed lines are capable of synthesizing $f t z$ protein and that the pro- 
tein is transported into the nucleus, we looked for an indication that protein synthesized in this manner is functional. This was tested by examining the cuticular phenotype of pharate first instar larvae that were heatshocked at $37^{\circ} \mathrm{C}$ between 2.5 and $3.5 \mathrm{hr}$ of development. As stated earlier, such treatment has been shown previously to produce a near-reciprocal deletion of segments in a complementary fashion to those deleted in $f t z^{-}$embryos (Struhl 1985). We also obtained similar results using our pHSftz transformant embryos (data not shown). Although this does not show whether or not the protein expressed from the $h s p 70$ promoter can perform the same functions as the endogenous protein, it indicates that it somehow interferes either with the distribution of other segmentation proteins or their ability to direct normal segment boundary formation in regions where $f t z$ is not normally expressed.

In summary, these three tests show that the ftz protein can be overproduced under the control of a heat shock promoter, that it is a nuclear protein, and that it is probably capable of some, if not most, of the endogenous $f t z$ protein functions.

\section{Post-translational modification of $\mathrm{ftz}$ protein}

As pointed out earlier, $f t z$ protein made in Drosophila embryos migrates more slowly on SDS-polyacrylamide gels than protein expressed in vitro or in E. coli. This suggests that the protein contains covalently bound modifications. To obtain more information about the nature of these modifications, protein samples were resolved further using two-dimensional PAGE (Fig. 4). Samples of $f t z$ protein made either in E. coli or in embryos were separated first by charge on isoelectric focusing gels and then by molecular weight on SDS-polyacrylamide gels. The $f t z$ protein was then detected by Western blotting. Figure 4A shows that $f t z$ protein expressed in $E$. coli predominantly forms a single spot. In addition, there is a weak spot shifted slightly to the acidic side of the gel and, on blots that have been developed longer, a third very faint spot can be detected even farther to the right. The pattern generated by purified protein stained with Coomassie blue is identical, indicating that all of these spots represent forms of the $f t z$ protein and that some modification occurs in bacterial cells.

In contrast, when $f t z$ protein was expressed uniformly throughout the embryo by heat-shocking pHSftz embryos, the protein was resolved into a series of at least 11 distinct isoforms (Fig. 4B). These increase in negative charge and apparent molecular weight with respect to the major species made in $E$. coli. The same pattern was observed using other pHS $f t z$ transformant embryos and is also essentially the same in heat-shocked pHS $\mathrm{ftz}$ third instar larvae (data not shown). The pattern seen in Figure 4B was generated from embryos collected overnight, aged for $2 \mathrm{hr}$, and then heat-shocked for $3 \mathrm{hr}$. Thus, the mixture of isoforms represented by this pattern is the average of all isoforms produced throughout the embryo between 5 and $18 \mathrm{hr}$ of embryogenesis.

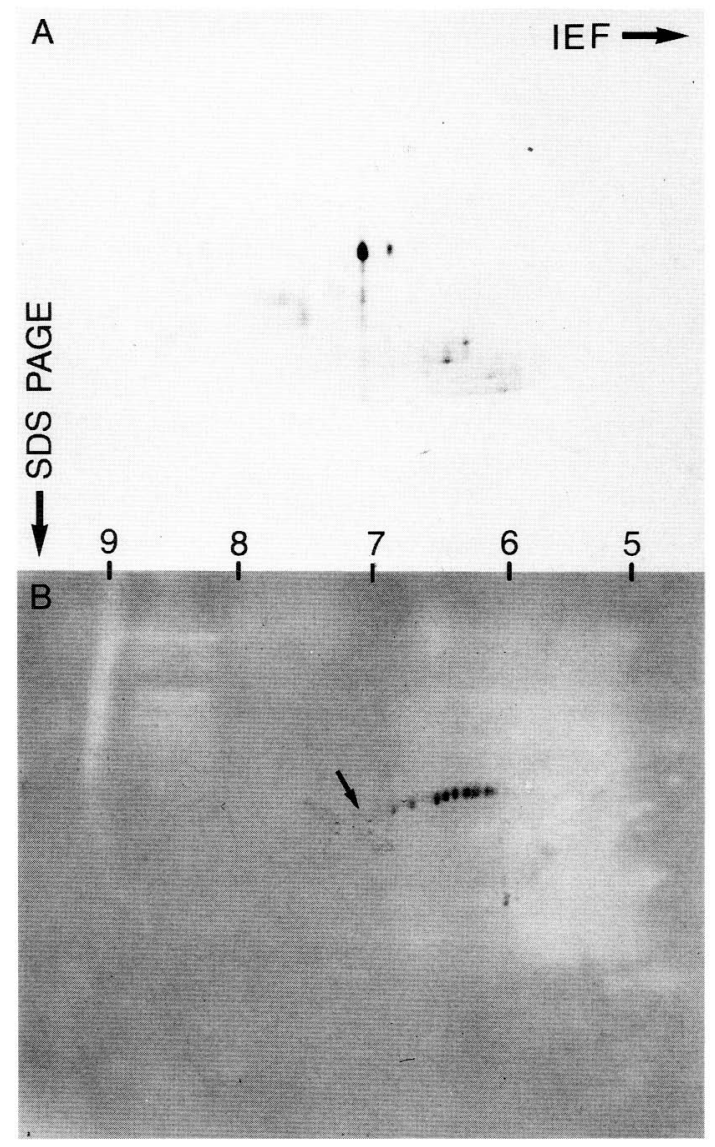

Figure 4. Two-dimensional analysis of $f t z$ protein modifications. Proteins were separated in the first dimension (left to right) by isoelectric focusing and in the second dimension (top to bottom) by SDS-PAGE. Proteins were transferred to nitrocellulose, and blots were developed with $\mathrm{ftz}$ antibodies and followed by enzymatic staining of a secondary antibody coupled to horseradish peroxidase. $(A) \mathrm{ftz}$ protein present in induced bacterial cultures; $(B) \mathrm{ftz}$ protein expressed ubiquitously throughout Drosophila embryos by heat-shocking AAl embryos from an overnight collection. $\mathrm{pH}$ values indicated between the two panels were determined by measuring the $\mathrm{pH}$ value of solutions containing pieces of sectioned isoelectric focusing gels. The arrow in $B$ indicates the approximate position at which the major species of $f t z$ protein expressed in $E$. coli would be located.

\section{Temporal and spatial expression of $\mathrm{ftz}$ protein during} embryogenesis

Earlier, it was shown that the $f t z$ antibodies detect a weak band on Western blots of total embryonic extracts (Fig. 2, lane 4). To demonstrate more conclusively that the protein detected is $f t z$ and that the antibody is specific for this protein, we examined variations in its abundance during different periods of embryogenesis using a 'developmental' Western blot (Fig. 5). In addition, we used immunological localization of $f t z$ protein on whole embryos to determine whether or not changes in abundance of the protein correlate with changes in 


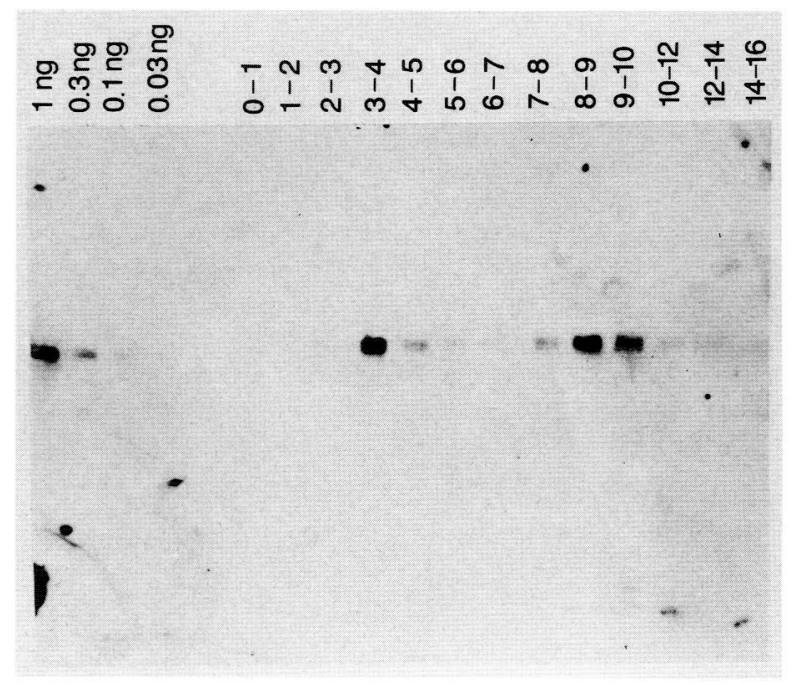

Figure 5. Western blot analysis showing developmental expression of $f t z$ protein in wild-type embryos. Embryos collected for $1-\mathrm{hr}(0-10 \mathrm{hr})$ or $2-\mathrm{hr}(10-16 \mathrm{hr})$ intervals were weighed and lysed in $4 \mu \mathrm{l} / \mathrm{mg}$ SDS-lysis buffer. The equivalent of $4 \mathrm{mg}$ of embryos was loaded in each lane, separated by SDS-PAGE, and blotted to nitrocellulose. $f t z$ protein was detected using $f t z$ antibodies and ${ }^{125} \mathrm{I}$-labeled protein $\mathrm{A}$. Time intervals indicating the ages of collected embryos are given, as are the amounts of $f t z$ protein purified from $E$. coli used as size and quantitation standards.

the patterns and sites of $f t z$ expression demonstrated previously (see Fig. 6).

The developmental Western blot was made using equivalent numbers of embryos collected and aged so that 1- or 2-hr intervals of embryogenesis are represented. Examination of Figure 5 shows that the band detected previously in Figure 2 (lane 4 ) first appears during the 3- to 4-hr interval of embryogenesis. It then subsides and reaches a second peak during the 8- to 9-hr interval. After $10 \mathrm{hr}$ of development, the protein abundance drops substantially. Upon overexpression of the blot, a band can still be detected during the 12- to $14-\mathrm{hr}$ interval ( $\leqslant 0.1 \mathrm{ng}$ protein). No protein is detectable after $14 \mathrm{hr}$. Hence, the expression of $f t z$ protein is in agreement with the fluctuations of $f t z$ mRNA reported previously, except that the protein is in higher relative abundance during the 8 - to 10 -hr interval than the message from which it is derived (see Kuroiwa et al. 1984; Weiner et al. 1984). The overall abundance of protein at $8-9 \mathrm{hr}$ is $\sim 75-80 \%$ of the amount present during the $3-$ to $4-\mathrm{hr}$ interval (based on several repetitions of the experiment and quantitation of bands). In contrast, the amount of message at $8-10 \mathrm{hr}$ is $\sim 10-20 \%$ of the abundance at 2-4 hr (Kuroiwa et al. 1984; Weiner et al. 1984). The nuclear concentration of $f t z$ protein during the 8- to 10-hr interval was not determined because both the numbers and sizes of nuclei expressing $f t z$ in the developing nervous system vary rapidly with time (see Fig. $6 \mathrm{D}-\mathrm{G})$.

Immunofluorescence on whole embryos shows that the two peaks of $f t z$ protein expression take place in different locations (as described previously by Carroll and Scott 1985). The embryos shown in Figure 6, A-C, demonstrate that $f t z$ protein present between 3 and $5 \mathrm{hr}$ of development is localized in seven zebra-like bands that encircle the embryo. We noted consistently that the bands appear in the following order: $2,1+3,5,6,7$, and finally, 4 . This order of appearance is reflected by the relative intensity of each stripe, as seen in the embryo in Figure 6A (stripes are arbitrarily numbered from anterior to posterior). At this point, it can also be seen that there is a gradient of protein abundance across the stripes; nuclei at the edges of the bands stain very weakly, whereas those in the center produce the strongest signal. This bell-shaped distribution is resolved quickly into stripes with well-defined borders in which all nuclei apparently possess the same level of $f t z$ protein and are flanked by nuclei that express no detectable protein (Fig. 6B).

The bands are dynamic in width and position, as discussed previously by Carroll and Scott (1985). In Figure $7 \mathrm{~B}$, nuclei on the posterior edges of most stripes that have intermediate levels of $f t z$ protein abundance can be seen. Carroll et al. (1988) have interpreted this to mean that subsequent stripe narrowing occurs predominantly by loss of $f t z$ protein in the cells representing the posterior edges of each stripe. Lawrence et al. (1987) arrived at the same conclusion previously by showing that the anterior edges of each $\mathrm{ftz}$ stripe remain lined up with engrailed stripes during the period of time that engrailed and $f t z$ are coexpressed. We must point out, however, that this only appears to be true for stripes $1-5$, because stripe 6 remains more or less constant at three to four cells in width, and stripe 7 becomes wider rather than narrower (see Fig. 6C). Because the cells are dividing during this time, the maintenance of stripe 6 at three to four cells in width is likely to involve a balance between the process of stripe narrowing due to loss of $f t z$ expression in certain cells and widening due to the division of other $f t z$-expressing cells.

After completion of germ-band extension, expression of $f t z$ protein becomes difficult to detect. Then, beginning at $\sim 5-6 \mathrm{hr}$ of development, when the stripes are no longer detectable, staining of distinct neuronal precursor cells in the developing nervous system becomes visible in each segment (Fig. 6D). These increase in number and eventually give rise to a large number of specifically labeled neurons. The pattern of expression in specific cells and the role of $f t z$ protein in these cells is being studied elsewhere (see Doe et al. 1988). Localization of $f t z$ protein in the blastoderm and nervous system confirms data reported previously (Carroll and Scott 1985).

Upon examination of older embryos, a third stage of expression was detected that has not been described previously (Fig. $6 \mathrm{H}$; Fig. 7). This expression appeared dorsally at about $40 \%$ egg length as a small ring or tube in 12- to 15 -hr-old embryos and was most prominent be- 


\section{Krause et al.}
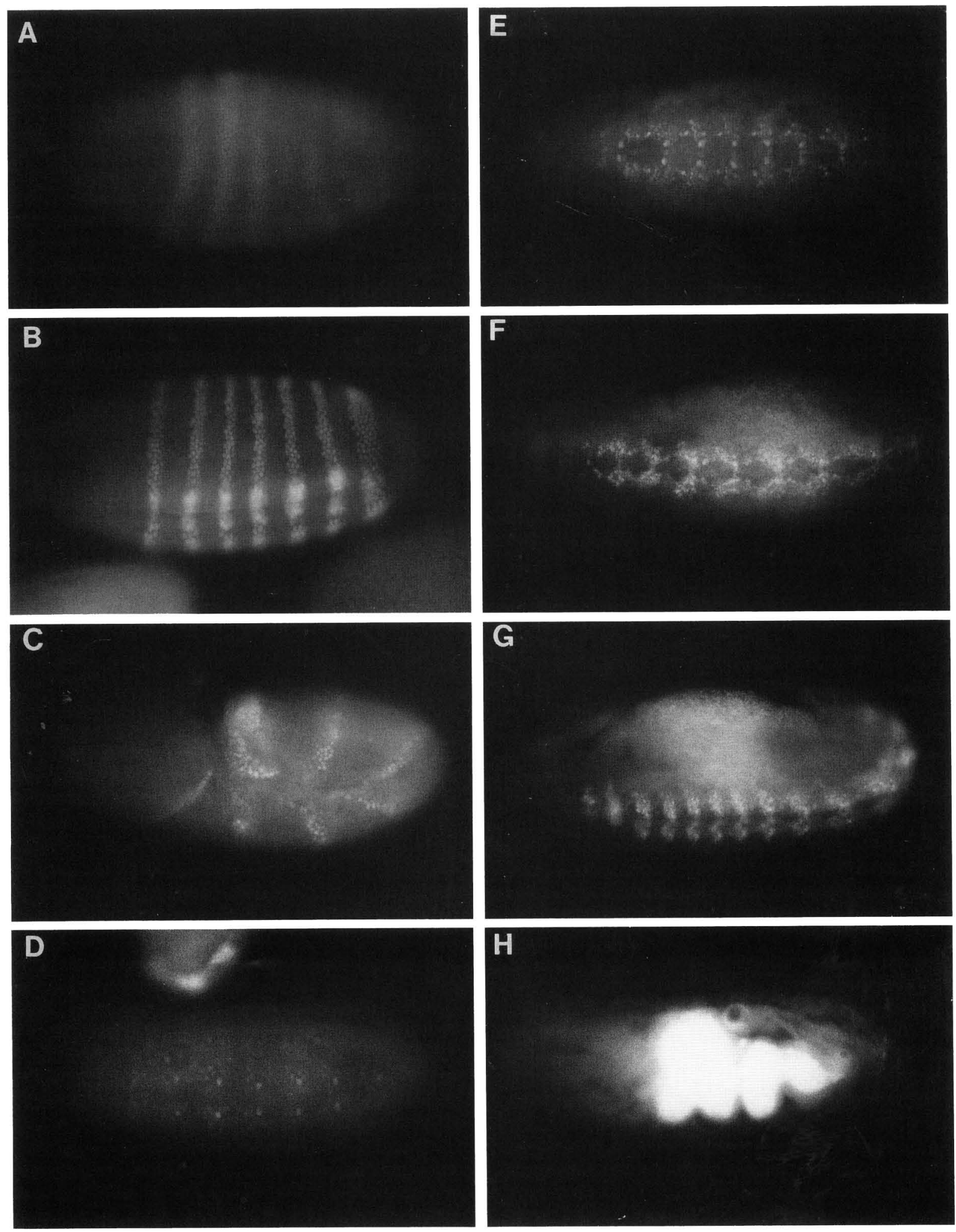

Figure 6. Immunofluorescence localization of $f t z$ protein expressed during embryogenesis. Staged embryos were incubated with anti-ftz antibodies, and a swine, anti-rabbit secondary antibody coupled to fluorescein. Embryos are oriented with the anterior end to the left and ventral surface down, except for $D-F$, which are viewed from the ventral side. Based on a 21-hr period of embryogenesis (at $25^{\circ} \mathrm{C}$ ) embryos are estimated to be $\sim 23 / 4 \mathrm{hr}(A), 3 \mathrm{hr}(B), 4 \mathrm{hr}(C), 6 \mathrm{hr}(D), 7 \mathrm{hr}(E), 9 \mathrm{hr}(F), 10 \mathrm{hr}(G)$, and $14 \mathrm{hr}$ old $(H)$. $(A-C)$ Stages of pair-rule stripe expression; $(D-G)$ nervous system expression; $(H)$ hindgut expression. After $9 \mathrm{hr}$ of development, autofluorescence of the yolk proteins present in the developing midgut can be detected and differs from the fluorescein signal in that it is yellow rather than green. 

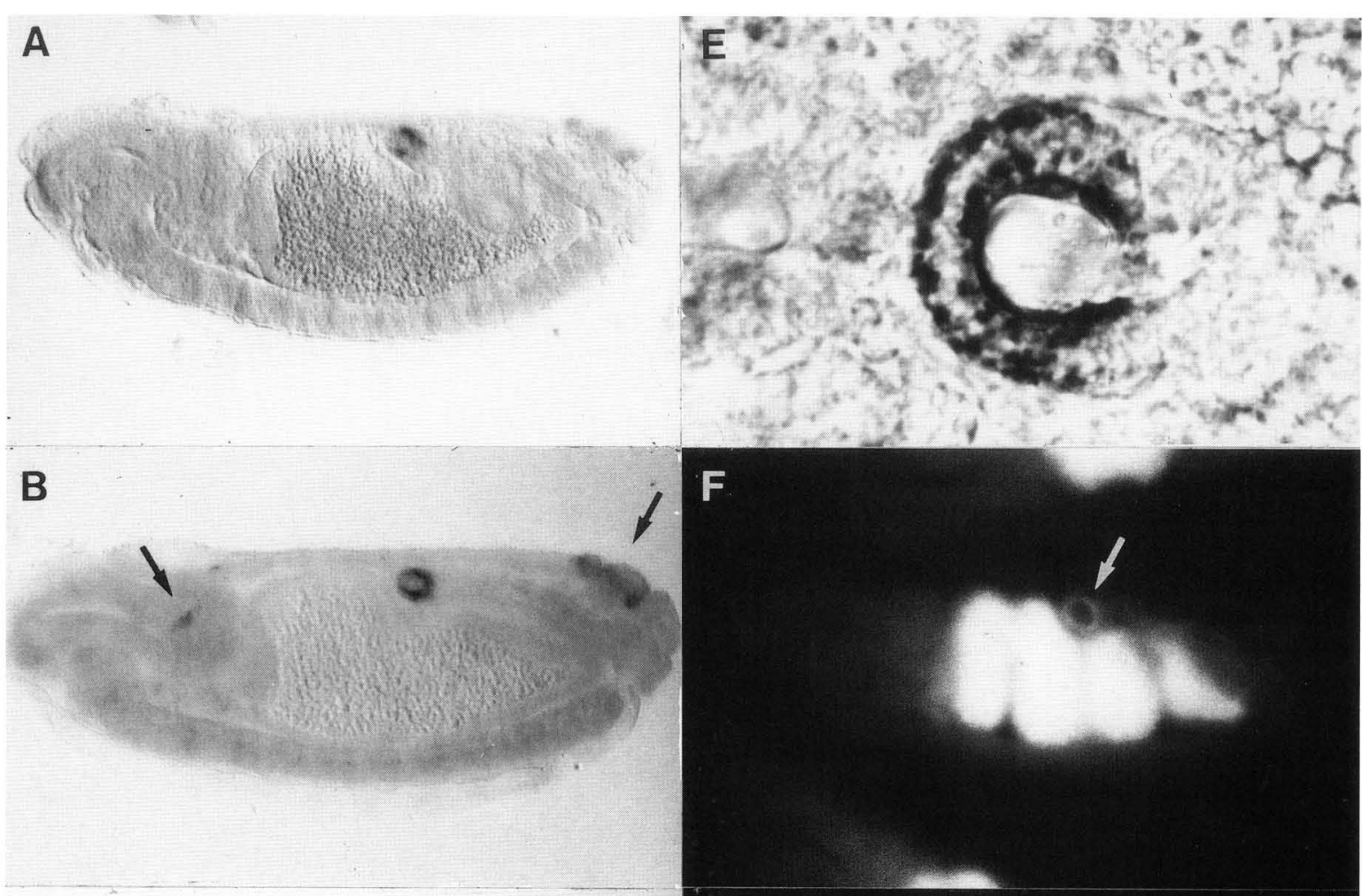

C
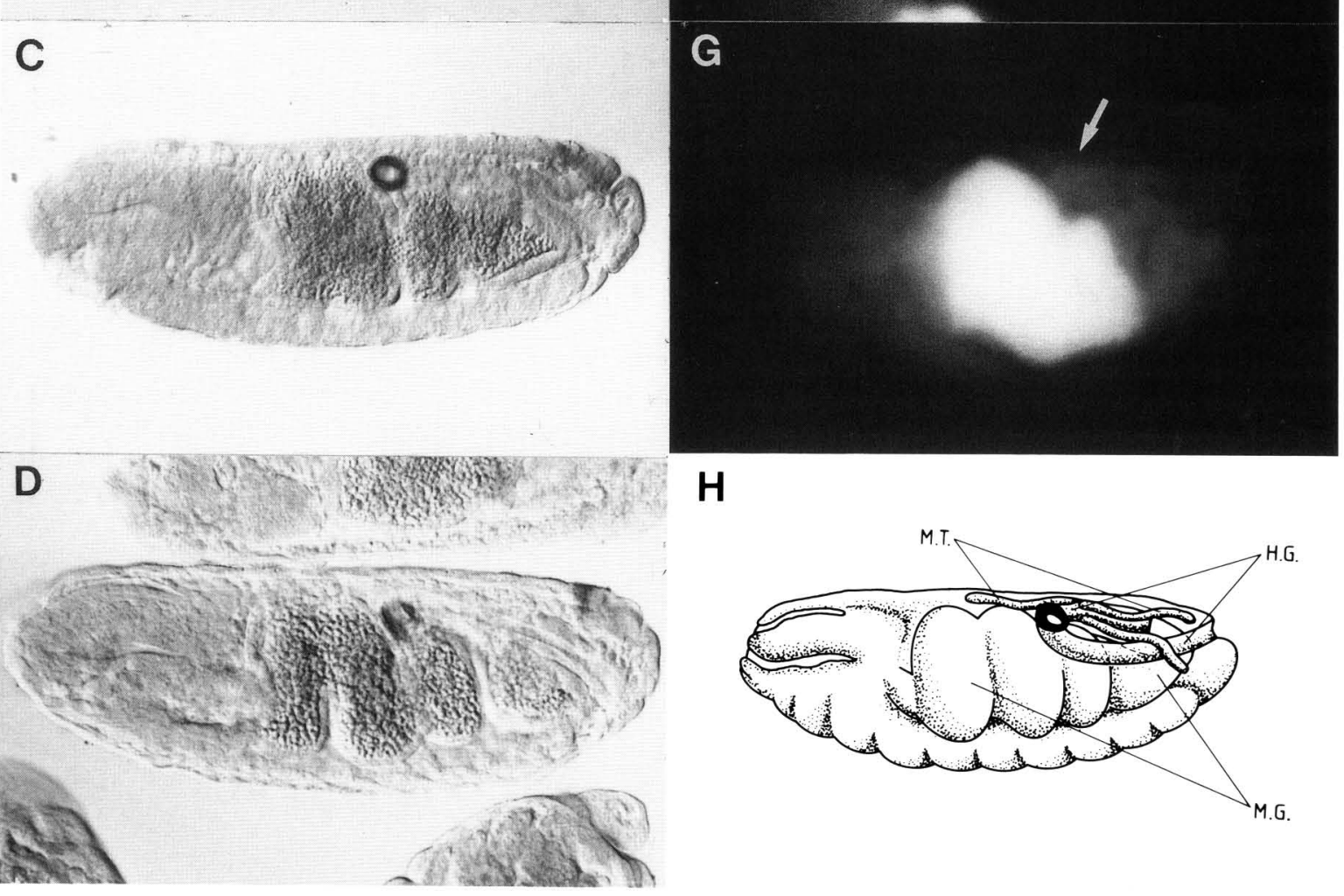

H

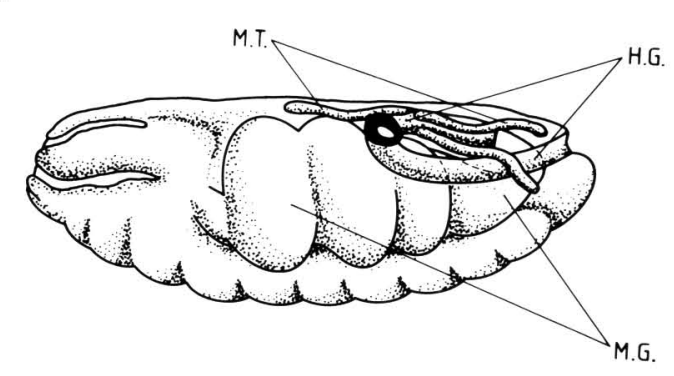

Figure 7. $f t z$ protein expressed in the hindgut. $f t z$ protein was detected using either fluorescein-coupled $(F, G)$ or peroxidase-coupled $(A-E, H)$ secondary antibodies. Lateral views are shown, with dorsal at the top and anterior to the left. $(A) \mathrm{A} 12$-hr- embryo; hindgut expression is just beginning, $(B)$ A 13-hr-old embryo. In addition to the hindgut staining, regions of expression are indicated in the anterior and posterior regions of the embryo (arrows). (C) A 14-hr-old embryo. (D) A 15-hr-old embryo, showing widening and weakening of the hindgut site of expression. $(E)$ A higher magnification of the hindgut expression site, showing nuclear localization. $(F)$ Fluorescent staining of a 14-hr-old wild-type embryo. (G) A 14-hr-old $f t z^{9 H 34}$ embryo, which does not express $f t z$ protein (Carroll and Scott 1985). (H) A diagrammatic interpretation of a 14-hr-old embryo showing relevant features. The site of $f t z$ expression in the hindgut is indicated as a solid black ring. (M.G.) Midgut; (M.T.) malpighian tubules; (H.G.) hindgut. 
tween 13 and $14 \mathrm{hr}$ of development (Fig. 7A-D). In addition, light staining was observed in the proximity of the proventriculus and on the dorsal posterior ectoderm (indicated in Fig. 7B). Because the yolk proteins located in the midgut are autofluorescent (Fig. 6G,H), localization of $f t z$ antibodies at this stage of development was generally performed with the aid of a secondary antibody coupled to horseradish peroxidase. The major site of expression, seen as a stained ring when viewed in cross section, coincides with a section of the hindgut just posterior to the site of malpighian tubule attachment (see Fig. 7H). At this point, the hindgut makes a major bend, with one end looping back to the posterior end of the embryo and the other extending past the malpighian tubules to the point where it fuses with the midgut. Expression begins as a short tube (Fig. 7A) that narrows during the peak of expression (Fig. 7B,C) and then widens once more as expression drops off (Fig. 7D). As seen in the previous two phases of $\mathrm{ftz}$ expression, protein localization also appears to be nuclear (Fig. 7E). Similar staining patterns were obtained using antibodies from two different rabbits. Staining was not observed when preimmune serum or protein-negative $f z^{-}$embryos were used (Fig. 7F,G).

\section{Discussion}

Synthesis of $\mathrm{ftz}$ protein in heterologous systems

Expression of $f t z$ protein was achieved in an in vitro transcription-translation system and in E. coli using the $\mathrm{T} 7$ expression system. In both cases, the protein migrated anomalously on SDS-gels to approximately the same position, corresponding to an apparent molecular weight of 63,000 . Protein produced in either system is insoluble and can only be solubilized and maintained in solution in the presence of urea or guanidium hydrochloride. This tendency of $f t z$ protein to aggregate is probably an inherent property of the protein's amino acid composition and sequence and suggests that in Drosophila, the protein must be folded differently, modified, or maintained in solution by associating with other factors. Indeed, no indication of insolubility has been encountered during partial purification of $f t z$ protein from Drosophila embryos (H.M. Krause and W.J. Gehring, in prep.).

Analysis of the $f t z$ DNA sequence predicts an unusually high abundance of proline, serine, threonine, and tyrosine residues $(10 \%, 10 \%, 10 \%$, and $9 \%$, respectively $)$. The first three are characteristic components of 'PEST' sequences $(\mathrm{P}=$ proline, $\mathrm{E}=$ lysine, $\mathrm{S}=$ serine, $\mathrm{T}=$ threonine), which have been found in a large number of eukaryotic proteins that are degraded rapidly (see Rogers et al. 1986). One could also imagine that repetition of these amino acids, the prolines in particular, could create defined kinks or bends in the secondary structure of the protein. These might facilitate protein aggregation and possibly inhibit quantitative binding and denaturation by SDS, thus affecting mobility in SDS-polyacrylamide gels as well.

Rapid degradation of the $f t z$ protein in E. coli may have been the decisive factor that resulted in the failure of all but the $\mathrm{T} 7$ expression system to produce detectable levels of protein. The developers of the system claim that transcription and translation of the $\mathrm{T} 7$ polymerase transcribed gene in bacterial cells monopolizes all of the available resources. Thus, in the case of a protein that is extremely labile, this may preclude a host response sufficient to remove the levels of protein being synthesized. In addition, the T7 RNA polymerase is present in higher abundance, elongates more rapidly, and is less sensitive to termination than the E. coli RNA polymerase. Even so, $f t z$ protein accumulation was far below the levels that have been reported for other proteins expressed in this system.

\section{$\mathrm{ftz}$ antibodies are specific for $\mathrm{ftz}$ protein}

$f t z$ protein purified from E. coli, as described, was used to generate antibodies in rabbits. That the protein used to generate antibodies is $\mathrm{ftz}$ and that the antibodies recognize this protein as well as the Drosophila-made $\mathrm{ftz}$ protein, is shown by mutually agreeing experiments. On Western blots, the antibodies recognize only the $63-\mathrm{kD}$ band of an induced $E$. coli lysate and a slightly larger, fuzzy band of higher apparent molecular weight in extracts from wild-type embryos. Peaks in the abundance of this band correlate in time with the results of immunological staining of embryos. The antibody detects seven stripes of protein located in the ectodermal nuclei of 3- to 5-hr-old embryos and the nuclei of neuronal precursors in the developing nervous system of 6- to $12-\mathrm{hr}$ old embryos. These results are also consistent with previously reported Northern blots on which $f t z$ mRNA can be detected at similar times. A comparison of Northern and Western blots, however, shows that $f t z$ protein is higher in relative abundance during nervous system expression than the mRNA from which it is derived. This, taken together with the fact that mRNA expression in the nervous system was not detected initially by in situ hybridization and that the protein is easily detectable by immunofluorescence, suggests that the efficiency of $f t z$ mRNA translation or protein stability must be significantly higher in the nervous system.

It was found that rabbits injected with $f t z$ protein consistently produced antibodies with high specific affinity for native, as well as denatured, $f t z$ protein and generally showed very low background. Immunological staining of whole embryos produced essentially the same results using serum dilutions ranging from $1: 100$ to $1: 1000$, indicating a high titer of $f t z$-specific antibodies. No difference in staining patterns was detected using $f t z$ antibodies that were purified over a ftz protein affinity column. It is possible that the high titer and specificity 
of the rabbit sera may be partially attributable to the use of a purified and full-length, nonfusion protein that was injected in a seminative state to generate these antibodies.

\section{The heat shock-ftz promoter fusion}

Although engrailed and $f t z$ proteins synthesized in $E$. coli bind DNA in a sequence-specific manner, the binding sites are numerous and variable in sequence (Desplan et al. 1985; Krause and Gehring 1988, and unpubl.). Because problems in the solubility of these proteins were also observed, we wished to identify and compare the $f t z$ protein made in Drosophila embryos with protein made in heterologous systems to see whether biochemical differences could be detected. It became obvious that normal expression of the protein in embryos was at the threshold of detection on immunoblots. A $f t z$-heat shock promoter fusion was therefore constructed so that elevated levels of $f t z$ protein could be synthesized in Drosophila embryos. Use of the hsp 70 heat shock promoter has the additional advantage of allowing temporal control of induction. By heat shocking pHS $f z$ transformants, it was found that synthesis of $f t z$ protein could be induced at all times during development and in all tissues examined, except perhaps prior to $2 \mathrm{hr}$ of embryogenesis. Furthermore, the protein migrates to the nuclei of these cells as it does during normal expression in wild-type embryos and comigrates with the endogenous protein on SDS-polyacrylamide gels. In previous experiments, Struhl (1985) has shown that $f t z$ protein expressed from the hsp70 promoter by heat shock during the blastoderm period of development disrupts the normal pattern of segmentation. Here, we have shown that heat shock does indeed produce $f t z$ protein in his and our transformants and that the protein is distributed uniformly throughout the blastoderm nuclei as expected. Maximal levels of $f t z$ protein produced by these transformants were less than expected, being only 20-40 times higher than in 3- to 4-hr-old wild-type embryos. This is not much more than the value that might be expected if one considers that the whole volume of 5- to 18-hr-old embryos (the usual age after overnight collection, staging, and heat shock) is capable of expressing $\mathrm{ftz}$ protein rather than just the $2100 \mathrm{ftz}$-expressing nuclei that encircle the periphery of a normal blastoderm embryo. We have found that the $f t z$ protein is extremely labile, both in E. coli and Drosophila, and this may quite possibly be the major factor that inhibits further accumulation in these cells. Edgar et al. (1986) have estimated that the half-lives of $f t z$ mRNA and protein are $\sim 10$ and $6 \mathrm{~min}$, respectively, during the blastoderm stage of expression. In contrast, under similar heat shock conditions, the various heat shock proteins can each accumulate to values approaching $1 \%$ of total cellular protein (Ashburner and Bonner 1979; Dura 1981). We estimate that the amount of $f t z$ protein maximally produced is about 2 orders of magnitude lower. That proteins involved in embryonic development have a rapid turnover rate is perhaps not surprising as changes in developmental states must occur very rapidly to complete embryogenesis in a mere $21 \mathrm{hr}$.

\section{ftz protein is covalently modified in Drosophila}

On two-dimensional gels, $f t z$ protein made in $E$. coli migrates predominantly as a single spot. The $\mathrm{pH}$ of the isoelectric focusing gels at this position is $\sim 7$. This value is in agreement with the $\mathrm{pI}$ value of 6.8 calculated for the protein based on its amino acid sequence. A very weak spot that comigrates with this one can also be detected in extracts from heat-shocked pHSftz transformant embryos. Because all other spots detected are increasingly negatively charged, this spot probably represents the unmodified form of the protein. Interestingly, two weak spots were also seen on two-dimensional gels, both before and after purification of the bacterially expressed protein. Thus, it appears that $E$. coli possesses the ability to modify the $f t z$ protein covalently, although the percentage of modified protein and the number of modifications on each protein molecule were minimal under these conditions of expression. Because these isoforms of the protein also run more slowly in the SDS-PAGE dimension, it is unlikely that they are generated by the removal of amino acids due to proteolytic degradation. Protein translated in vitro in a reticulocyte lysate comigrated with the protein synthesized in E. coli, suggesting that it is also not modified extensively. In vitro-translated protein was not examined on two-dimensional gels.

$f t z$ protein made in either wild-type Drosophila embryos or by heat shock in pHSftz-transformed embryos comigrate on SDS-polyacrylamide gels as broad bands which run more slowly than protein made in either of the two heterologous systems. When the protein overexpressed by heat shock was resolved on two-dimensional gels, at least 11 distinct spots could be detected. These appear to represent isoforms of the $f t z$ protein which possess increasing numbers of covalently bound negative modifications as they become shifted from left to right on the two-dimensional gels. We have also detected complex patterns of spots in wild-type embryo extracts at stages when the protein is expressed maximally and also when expressed under the control of a heterologous promoter in the flight muscles of adult flies (H.M. Krause and W.J. Gehring, in prep.). Thus, it is unlikely that the process of heat shock is responsible for the creation of these isoforms. However, it may have an influence on the number and nature of modifications made to the protein. Several types of post-translational modifications could produce the type of pattern observed. The results of further experiments indicate that the process giving rise to these multiple isoforms is protein phosphorylation (H.M. Krause and W.J. Gehring, in prep.).

Post-translational modification of the $f t z$ protein during embryogenesis could conceivably alter the regulatory potential of the protein by altering various biochemical properties. For example, the tendency of the unmodified protein made in heterologous systems to ag- 
gregate could be modulated by the addition of negatively charged groups to hydrophobic regions of the protein. In key positions, they could also alter the ability of the protein to bind DNA sequence specifically or to interact with other proteins such as transcription factors. Because the embryonic pattern of $f t z$ protein produced on two-dimensional gels represents protein expressed during a great portion of embryogenesis, and throughout the embryo, it will be interesting to see whether distinct subpopulations of the observed isoforms are localized to specific regions during different stages of $f t z$ expression.

\section{Three phases of expression during embryogenesis}

The high affinity of our $f t z$ antibodies permitted the observation of very early and late phases of the segmentation and nervous system periods of $f t z$ expression. In situ hybridization to $f t z$ mRNA shows that the message is first detectable in a fairly uniform distribution over the seven-stripe domain (Hafen et al. 1984). This pattern then becomes resolved into the seven stripes reflected by the RNA (Hafen et al. 1984; Weir and Kornberg 1985; Edgar et al. 1986) and protein distribution (Carroll and Scott 1985). The earliest unambiguous expression of $f t z$ protein that we detected is in a striped pattern at late blastoderm stages. The appearance of each stripe occurs in a consistent, defined order, as represented by the different stripe intensities of the fixed embryo in Figure 6A. This intermediate pattern can also be seen in the intermediate patterns of $f t z$ transcript distribution (Hafen et al. 1984; Weir and Kornberg 1985; Edgar et al. 1986). Embryos that exhibited a uniform or double-wide intermediate stripe distribution were not observed.

Antibody detection at these initial stages of expression demonstrates the occurrence of rapid changes in stripe intensity and definition. At the onset of detection, nuclei at the edges of the stripes contain lower levels of $f t z$ protein than those in the center. The quick transition to a state where nuclei at the edges of the bands either do or do not contain equivalent amounts of $f t z$ protein is compatible with the models proposed by Meinhardt and Gierer (1980; Meinhardt 1986). To fit these models, the $\mathrm{ftz}$ protein must be capable of autoregulating its own expression positively, whereas segmentation gene products expressed in adjacent and initially overlapping stripes must repress $f t z$ expression. The ratio of $f t z$ protein concentration to other competing segmentation proteins in a given nucleus, therefore, determines whether or not $\mathrm{ftz}$ becomes maximally expressed or is turned off. Only one of the competing genes would eventually be expressed in each nucleus, and the stripe borders would thus become sharply defined. Because the sharpening of the initial striped pattern occurs after cellularization, it appears that this resolution process occurs cell autonomously. Evidence for positive autoregulation by $f t z$ protein and repression of $f t z$ expression by other segmentation genes has been obtained through the use of $f t z$ promoter fusions to the $\beta$-galactosidase gene (Hiromi et al. 1985; Hiromi and Gehring 1987) and immunodetection of the protein expressed in various mutant backgrounds (Carroll and Scott 1986). After the initial resolution of the stripes, stripes $1-5$ become narrower and stripe 7 becomes wider. This appears to occur by the removal or addition of $f t z$-expressing nuclei at the posterior edges of the stripes, as demonstrated previously by Lawrence et al. (1987) and Carroll et al. (1988).

Comparisons of the abundance of $f t z$ protein during this first phase of expression with known amounts of $E$. coli protein on immunoblots permitted us to make a rough estimate of the concentration of $f t z$ protein in the nuclei in which the gene is expressed. This abundance is comparable to levels of other eukaryotic regulatory proteins. For example, the enhancer-activating proteins AP-1 and AP-2 also have an estimated abundance of 20,000 molecules per cell (Lee et al. 1987; Mitchell et al. 1987). These numbers can also be compared with levels of prokaryotic regulatory proteins. The $\lambda$ repressor, for example is present at $\sim 100-200$ copies per lysogen (Ptashne 1986). Because Drosophila blastoderm nuclei are $\sim 150$ times the volume of a bacterial cell $\left(150 \mu \mathrm{m}^{3}\right.$ vs. $\left.1 \mu \mathrm{m}^{3}\right)$, this abundance would also be equal to $\sim 20,000$ molecules per nucleus. Indeed, the estimated concentration of $\lambda$ repressor in a lysogen is the same as our estimated value for the concentration of $f t z$ protein in blastoderm nuclei $\left(\sim 2 \times 10^{-7} \mathrm{M}\right)$.

Nervous system expression of $f t z$ follows soon after the stripes have disappeared. The protein is first detectable between 5 and $6 \mathrm{hr}$ of development in the midline precursor-2 (MP-2) cells (Doe et al. 1988) in a segmentally repeating pattern. Expression in many other identified neuronal precursors follows and reaches a second peak of abundance at $\sim 9 \mathrm{hr}$ of development. At the end of germ-band retraction, the protein disappears. Although it is not yet clear what the role of the $f t z$ protein is during the development of the central nervous system, it has now been shown that failure to express $f t z$ leads to a change in cell identity in the case of at least one pair of segmentally repeated neurons (Doe et al. 1988).

Following nervous system expression of the protein, a previously undetected phase of expression was observed. This phase begins at $\sim 11.5 \mathrm{hr}$ of development and persists until approximately the fifteenth hour of development. This is the only nonsegmental expression of $f t z$ protein during embryogenesis and is predominantly localized to a section of the hindgut just posterior to the attachment site of the malpighian tubules. After the peak of expression at $13 \mathrm{hr}$, the ring seems to widen into a tube that partially overlaps the major bend in the hindgut (diagramed in Fig. $7 \mathrm{H}$ ). As the embryo develops further, the signal disperses and weakens. In addition to this site of expression, protein was usually detectable at the posterior, dorsal surface of the embryo and in a few cells in the foregut. Again, as in the previous phases of expression, the protein localization is nuclear. Although no protein can be detected on the developmental Western blot at this time in development, examination of the Northern blots of Weiner et al. (1984) shows that some $f t z$ mRNA is still present at low levels in 12- to 
14-hr-old embryos. The band corresponding to $\mathrm{ftz}$ protein in the developmental Western blot was also detectable at this stage of development.

Several other lines of evidence are consistent with the assumption that the protein detected at this stage is $f t z$. Hindgut expression was detected with $f t z$ antibodies produced in two different rabbits, either before or after affinity purification of $f t z$ antibodies and not with preimmune serum from these same rabbits. Also, in homozygous $f t z^{9 H 34}$ embryos, which are $f t z$ protein negative (Carroll and Scott 1985), the hindgut was usually present, but immunostaining was absent. The possibility that the signal is due to cross-reactivity with another protein bearing similar epitopes is also unlikely because the antibodies appear to recognize only the $f t z$ protein on immunoblots.

Further evidence that $f t z$ is expressed and has a function in the hindgut is given in a study by Wakimoto et al. (1984). Flies carrying a temperature-sensitive $f t z$ allele were heat-shocked at different times during embryonic development. Decreased viability was observed when heat shocks were administered before $4 \mathrm{hr}, \sim 8 \mathrm{hr}$, and again at $12 \mathrm{hr}$ of development. It might also be mentioned that expression of the genes hairy, engrailed, Ultrabithorax, and caudal have been detected in parts of the midgut or hindgut during similar periods of embryogenesis (Akam and Martinez-Arias 1985; DiNardo et al. 1985; Fjose et al. 1985; Ingham et al. 1985; Kornberg et al. 1985; Mlodzik et al. 1985).

In light of these data, it seems that certain homeotic and segmentation genes not only play a role in the process of segmentation but in nervous system and gut development as well. It is not immediately obvious what the common requirement for $f t z$ protein might be in such functionally diverse tissues. It is possible that each tissue responds to $f t z$ expression in a similar way or that each tissue or cell interprets the presence of the protein in an individual fashion. For example, during different phases of expression, different subsets of genes might be regulated by the $f t z$ protein due to such variations as the presence or absence of different coregulatory factors or alterations in chromatin structure. Already, there is evidence that at least some of the genes that regulate $f t z$ and others that are regulated by $f t z$ vary during the blastoderm and nervous system periods of expression (Hiromi et al. 1987; Doe et al. 1988). In this respect, it will be interesting to see whether protein modification may also play a role in determining which genes are controlled by $f t z$ during different phases of development.

\section{Methods}

\section{Plasmids}

The expression of $f t z$ protein in E. coli necessitated the construction of the plasmid pGEMF1 (Fig. 1A). This was made by subcloning an EcoRI fragment from a previously constructed plasmid into the pGEM-1 plasmid (Promega Biotec), using standard cloning techniques (Maniatis et al. 1982). The donor plasmid, pDSBH2, was constructed and kindly provided by Johannes Wirz. The construction of the pDSBH2 plasmid in- volved a series of cloning steps in which $f t z$ genomic and cDNA restriction fragments isolated from various plasmids were ligated together to generate the complete reading frame of the protein with the intron deleted. In the final step, a 1590-bp BalI-EcoRI $f t z$ restriction fragment was inserted into the expression plasmid pDS6 (Stüber et al. 1984), using the BamHI and EcoRI sites of that plasmid. To make pGEMF1, an EcoRI fragment that includes $30 \mathrm{bp}$ of the original pDS6 plasmid was subcloned from pDSBH2 into pGEM-1 such that the T5 phage Shine-Dalgarno sequence present in that plasmid is also utilized in the new construct. In the pGEMF1 plasmid, the orientation of the EcoRI fragment places the inserted $f t z$ gene under the control of the $\mathrm{T} 7$ promoter, whereas it can be transcribed from the SP6 promoter in a second control plasmid, pGEMF2.

The pHSftz construct was made by inserting a $1.8 \mathrm{-kb}$ KpnIEcoRI restriction fragment from the plasmid pryHF lobtained from Y. Hiromi) into the modified P-element vector pHT4 (for a description of pHT4, see Schneuwly et al. 1987). In addition to the complete $f t z$-coding region, the KpnI-EcoRI $f t z$ fragment contains $\sim 100$ bp of $5^{\prime} \mathrm{ftz}$ leader (to the SauIIIA site) and $400 \mathrm{bp}$ of 3 ' trailer sequences. Sticky ends were filled in with T4 DNA polymerase (Boehringer) and blunt-end-ligated into the unique KpnI site of pHT4.

\section{Purification of $\mathrm{ftz}$ protein from E. coli}

The plasmid pGEMF1 was first transformed, characterized, and maintained in the E. coli strain ED8739 in which T7 RNA polymerase-directed $f t z$ expression can be induced by infection with genetically engineered $\lambda$ phage (Studier and Moffat 1986). For maximal expression, the plasmid was transformed into the BL21 : DE3 lysogen, in which induction is achieved by addition of IPTG. Bacterial growth and vector induction were performed essentially as described by Studier and Moffatt (1986). Cells were grown for $2 \mathrm{hr}$ after the addition of $2 \mathrm{~mm}$ IPTG at a cell density corresponding to an $\mathrm{OD}_{600}$ reading of 1.0 .

Cells from 1 liter of culture were pelleted by a low-speed spin and resuspended in $5 \mathrm{ml}$ of $25 \%$ sucrose, $50 \mathrm{~mm}$ Tris- $\mathrm{HCl} / \mathrm{pH}$ 7.5). Cells were then frozen overnight at $-20^{\circ} \mathrm{C}$. The following steps were carried out on ice or at $4^{\circ} \mathrm{C}$ and in the presence of the following protease inhibitors: $0.1 \mathrm{mM}$ phenylmethylsulfonyl fluoride (PMSF) (Sigma), $5 \mu \mathrm{g} / \mathrm{ml}$ leupeptin (Fluka), $0.2 \mu \mathrm{m} / \mathrm{ml}$ kalikrein (CalBiochem), and $2 \mu \mathrm{g} / \mathrm{ml}$ pepstatin (Fluka). Cells were thawed and resuspended in an equal volume of lysis buffer [100 mM Tris-HCl (pH 7.5), 4 mM EDTA, 2 mM dithiothreitol (DTT), and $2 \mathrm{mg} / \mathrm{ml}$ lysozyme] and incubated for $15 \mathrm{~min}$. This was followed by sonication in four 15-ml Falcon tubes for 15 $\mathrm{sec}$, repeated four times with not less than $1 \mathrm{~min}$ between repetitions. The lysate was spun at $14,000 \mathrm{rpm}$ for $10 \mathrm{~min}$ in a Sorval SS-34 rotor, and the pellet was washed twice by resuspending in $20 \mathrm{ml}$ resuspension $(\mathrm{R})$ buffer $10 \mathrm{mM}$ Tris- $\mathrm{HCl}$ at $\mathrm{pH} 7.5,100 \mathrm{~mm} \mathrm{NaCl}, 1 \mathrm{~mm}$ EDTA, $10 \%$ glycerol), first containing $1 \%$ Triton $\mathrm{X}-100$ and then $3 \mathrm{M}$ potassium thiocyanate. Each time, the mixture was resuspended using a Dounce homogenizer, and repelleted as above. Finally, $f t z$ protein was solubilized by resuspending in $10 \mathrm{ml} \mathrm{R}$ buffer containing deionized $8 \mathrm{M}$ urea, and after adding an equal volume of $\mathrm{R}$ buffer-urea insoluble material was removed by centrifugation for $10 \mathrm{~min}$ at $14,000 \mathrm{rpm}$ in a Sorvall SS-34 rotor. The supernatant was then passed through a $1.5 \times 10-\mathrm{cm}$ DEAE-cellulose (Cellex D, BioRad) column and dialyzed against $\mathrm{R}$ buffer containing $50 \mathrm{mM}$ $\mathrm{NaCl}$ and $2 \mathrm{M}$ urea. Precipitated protein was again removed by centrifugation, and the supernatant was loaded on a $1 \times 10-\mathrm{cm}$ double-stranded DNA cellulose (Sigma) column. Bound protein was eluted with a $50-\mathrm{ml}, 50-500 \mathrm{mM} \mathrm{NaCl}$ linear gradient in $\mathbf{R}$ buffer containing $2 \mathrm{M}$ urea. The protein was identified by SDS- 
PAGE and eluted between 175 and $225 \mathrm{~mm} \mathrm{NaCl}$. Fractions containing $f t z$ protein were pooled, and the majority were stored at $4^{\circ} \mathrm{C}$ for immediate studies. Aliquots were also prepared and stored at $-70^{\circ} \mathrm{C}$.

\section{In vitro transcription-translation}

RNA was transcribed in vitro from the plasmids pDSBH2 and pASF1 (in this plasmid, $f t z$ is under the control of the $\lambda P_{L}$ promoter in the vector pAS-1; Mott et al. 1985), using E. coli RNA polymerase, or from the plasmid pGEMF1 using T7 RNA polymerase. Both enzymes were obtained from Boehringer Mannheim. In vitro translation was carried out according to the procedure of Hurt et al. (1984). Proteins labeled with ${ }^{35}$ S|methionine (Amersham) translated in a rabbit reticulocyte lysate (kindly provided by G. Schatz, Biozentrum, University of Basel) were separated by SDS-PAGE and detected by autoradiography using fluorography and Dupont intensifying screens.

\section{Antibody preparation, purification, and manipulations}

Antibodies were generated in rabbits against full-length, native $f t z$ protein purified as described above. $f t z$ protein $(250 \mu \mathrm{g})$ in $250 \mu \mathrm{l} \mathrm{R}$ buffer containing $2 \mathrm{M}$ urea was mixed with an equal volume of complete Freund's adjuvant and injected subcutaneously at multiple sites. Secondary boosts were performed similarly with $50 \mu \mathrm{g}$ of protein every month for 4 months. Rabbits were bled every 2-4 weeks until final exsanguination.

Western blot analysis and immunolocalization of $f t z$ protein in embryos was generally performed with crude serum. As a control, antibody was purified further either by adsorption against 16- to 20-hr-old embryos or by affinity purification on a $f t z$ protein-Affi-Gel column. Preadsorption was achieved by incubating $200 \mu \mathrm{l}$ of crude serum with $0.5 \mathrm{ml}$ of fixed 16- to 20 -hr-old embryos in a total of $1 \mathrm{ml}$ of whole-mount solution A [ $1 \times$ PBS, 0.05\% Saponin, 0.05\% Triton X-100, 0.05\% NP-40, $0.05 \%$ deoxycholate (DOC), $2 \mathrm{mg} / \mathrm{ml}$ bovine serum albumin (BSA), and $0.02 \% \mathrm{NaN}_{3}$ ] overnight at $4^{\circ} \mathrm{C}$ with end-over-end rotation. Embryos were subsequently removed by a 1-min spin in an Eppendorf centrifuge.

For affinity purification, $2 \mathrm{mg}$ of $f t z$ protein purified from $E$. coli was dialyzed against $10 \mathrm{mM}$ morpholinopropanesulfonic acid (MOPS) pH 7.0, $100 \mathrm{~mm} \mathrm{NaCl}, 1 \mathrm{~mm}$ DTT, and $2 \mathrm{M}$ urea. Preparation of Affi-Gel 10 (Bio-Rad) and coupling of protein were performed as described by the manufacturer. Coupling was allowed to proceed for $4 \mathrm{hr}$ at $4^{\circ} \mathrm{C}$ with a $1: 1 \mathrm{vol} / \mathrm{vol}$ ratio of ligand to Affi-Gel. Crude serum $(20 \mathrm{ml})$ was passed over the $1-\mathrm{ml} f t z$ protein-Affi-Gel column, and bound antibody was eluted with $0.2 \mathrm{~N}$ glycine- $\mathrm{HCl}(\mathrm{pH} 2.8)$. The eluate was neutralized immediately with Tris- $\mathrm{HCl}(\mathrm{pH} 8.0)$ and dialyzed against PBS.

Embryos were prepared for immunolocalization using a variation of the protocol described by Mitchison and Sedat (1983). Embryos were dechorionated for $90 \mathrm{sec}$ in a 3\% Clorox solution and washed extensively. Fixation was carried out for $30 \mathrm{~min}$ at room temperature with moderate shaking in equal parts of heptane and a solution containing $100 \mathrm{mM}$ PIPES (pH 6.9), $2 \mathrm{mM}$ EGTA, $1 \mathrm{~mm} \mathrm{MgSO}_{4}$, and $5 \%$ formaldehyde. The lower aqueous phase was then removed and replaced by an equal volume of methanol. Vitelline membranes were removed by shaking vigorously for 3-5 min. Intact embryos were allowed to settle, and all liquid was removed. This was followed by three methanol washes and resuspension in whole-mount solu- tion A (described above). Embryos were stored for no longer than 2 days before use. If used immediately, embryos were incubated for $30 \mathrm{~min}$ in whole-mount solution A with end-overend rotation at room temperature. Antibody binding was carried out in whole-mount solution $\mathrm{B}(1 \times \mathrm{PBS}, 0.1 \%$ Triton $\mathrm{X}-1200,2 \mathrm{mg} / \mathrm{ml} \mathrm{BSA}, 5 \%$ swine serum, $0.02 \% \mathrm{NaN}_{3}$ ) for $2 \mathrm{hr}$ under the same conditions. $f t z$ antibodies were used at a dilution of $1: 500$. Swine anti-rabbit antibody coupled to fluorescein (Dako) was generally used as the secondary antibody at a $1: 100$ dilution. When peroxidase coupled to swine anti-rabbit serum (Dako) was used as the secondary antibody, washed embryos were stained in PBS containing $20 \mu \mathrm{g} / \mathrm{ml}$ diaminobenzidine (Sigma) and $0.003 \%$ hydrogen peroxide. The reaction was stopped by washing in PBS and followed by dehydration in washes of $70 \%, 90 \%$, and $100 \%$ ethanol. The embryos were then resuspended in DePeX mounting medium (Gurr) and mounted on a glass slide under a coverslip.

\section{Characterization of $\mathrm{ftz}$ protein modifications}

Samples of $f t z$ protein made in Drosophila embryos were prepared for one- and two-dimensional polyacrylamide gel analysis simply by homogenizing embryos directly in the appropriate loading buffer. The pHSftz transformant lines AA1-AA24 were generated by P-element-mediated germ-line transformation using standard techniques (Rubin and Spradling 1982), with the recipient fly line $\mathrm{R}-3$ (ry506, st, th, e). Embryos or larvae were collected and cleaned before heat shock in a $37^{\circ} \mathrm{C}$ incubator in a moist container. Embryos were dechorionated, blotted dry, and weighed. For one-dimensional gels, a minimum of $50 \mathrm{mg}$ of staged embryos were homogenized and boiled for $5 \mathrm{~min}$ in 4 $\mu \mathrm{l} / \mathrm{mg}$ SDS-lysis buffer and spun for $2 \mathrm{~min}$ in an Eppendorf centrifuge to remove insoluble material. The equivalent of 4-mg embryos (wet weight) were loaded on SDS-polyacrylamide gels. Western blots were made by transferring proteins separated by SDS-PAGE to nitrocellulose, as described by Towbin et al. (1979). Nonspecific binding of antibodies was blocked with BLOTTO (Johnson et al. 1984). ftz antibodies were bound at room temperature over a 2 -hr period at a dilution of $1: 1000$ and visually localized by labeling with ${ }^{125}$ I-labeled protein $A$ and autoradiography using preflashed film and intensifying screens. Sections of the blot containing $f t z$ protein were then cut out and counted in scintillation fluor. For two-dimensional analysis of proteins (O'Farrell 1985), embryos were lysed directly in $4 \mu \mathrm{l} / \mathrm{mg}$ isoelectric focusing lysis buffer. After SDSPAGE in the second dimension, immunoblotting was carried out as described above, except that the second antibody used was swine anti-rabbit coupled to peroxidase (Dako). Enzymatic development was performed as described above for the wholemount staining of embryos.

\section{Acknowledgments}

We would like to thank Johannes Wirz and Yasushi Hiromi for providing the plasmids that served as forerunners of plasmids used in this study. We would also like to acknowledge Denice Smith for providing her expertise in the production of $f t z$ antibodies and Dr. Dietrich Stüber (Hoffmann-La Roche Inc., Basel) for providing the T5 vector. We would like to thank other members of the lab-Rebecca Pearson, Hugo Bellen, Clive Wilson, and Leslie Pick-for critical reading of the manuscript. Special thanks go to Erika Wenger-Marquardt for manuscript preparation. H.K. was supported by the National Sciences and Engineering Research Council of Canada and the Sandoz Foundation. R.K. was supported by the Kantons of Basel. 


\section{References}

Akam, M.E. and A. Martinez-Arias. 1985. The distribution of Ultrabithorax transcripts in Drosophila embryos. EMBO $J$. 4: $1689-1700$.

Ashburner, M. and J. Bonner. 1979. The induction of gene activity in Drosophila by heat shock. Cell 17: 241-254.

Carroll, S.B. and M.P. Scott. 1985. Localization of the fushi tarazu protein during Drosophila embryogenesis. Cell 43: 47-57.

- 1986. Zygotically active genes that affect the spatial expression of the fushi tarazu segmentation gene during early Drosophila embryogenesis. Cell 45: 113-126.

Carroll, S.B., S. DiNardo, P.H. O'Farrell, R. White, and M.P. Scott. 1986. Temporal and spatial relationships between segmentation and homeotic gene expression in Drosophila embryos: Distributions of the fushi tarazu, engrailed, Sex combs reduced, Antennapedia, and Ultrabithorax proteins. Genes Dev. 2: 350-360.

Desplan, C., J. Theis, and P.H. O'Farrell. 1985. The Drosophila developmental gene, engrailed, encodes a sequence-specific DNA binding activity. Nature 318: 630-635.

Doe, C.A., Y. Hiromi, W.J. Gehring, and C.S. Goodman. 1988. Expression and function of the segmentation gene fushi tarazu during Drosophila neurogenesis. Science 236: 55-63.

DiNardo, S., J.M. Kuner, J. Theis, P.H. O'Farrell. 1985. Development of embryonic pattern in D. melanogaster as revealed by accumulation of the nuclear engrailed protein. Cell 43: $59-69$.

Dura, J.-M. 1981. Stage dependent synthesis of heat shock induced proteins in early embryos of Drosophila melanogaster. Mol. Gen. Genet. 154: 381-385.

Edgar, B., M. Weir, G. Schubiger, and T. Kornberg. 1986. Repression and turnover pattern of fushi tarazu RNA in the early Drosophila embryo. Cell 47: 745-754.

Fainsod, A., L.D. Bogard, T. Ruusala, M. Lubin, D.M. Crothers, and F.H. Ruddle. 1986. The homeodomain of a murine protein binds $5^{\prime}$ to its own homeobox. Proc. Natl. Acad. Sci. 83: 9532-9536.

Fjose, A., W.J. McGinnis, and W.J. Gehring. 1985. Isolation of a homoeobox-containing gene from the engrailed region of Drosophila and the spatial distribution of its transcripts. Nature 313: 284-289.

Gehring, W.J. and Y. Hiromi. 1986. Homeotic genes and the homeobox. Annu. Rev. Genet. 20: 147-173.

Hafen, E., A. Kuroiwa, and W.J. Gehring. 1984. Spatial distribution of transcripts from the segmentation gene fushi tarazu during Drosophila embryonic development. Cell 37: 833841.

Hall, M. and A. Johnson. 1987. Homeodomain of the yeast repressor Mat $\alpha 2$ is a sequence-specific DNA binding domain but is not sufficient for repression. Science 237: 1007-1011.

Hiromi, Y. and W.J. Gehring. 1987. Regulation and function of the Drosophila segmentation gene fushi tarazu. Cell 50: $963-974$.

Hiromi, Y., A. Kuroiwa, and W.J. Gehring. 1985. Control elements of the Drosophila segmentation gene fushi tarazu. Cell 43: 603-613.

Hurt, E.C., B. Pesold-Hurt, and G. Schatz. 1984. The amino-terminal region of an imported mitochondrial precursor polypeptide can direct cytoplasmic dihydrofolate reductase into the mitochrondrial matrix. EMBO I. 3: 3149-3156.

Ingham, P.W., K.R. Howard, and D. Ish-Horowicz. 1985. Transcription pattern of the Drosophila segmentation gene hairy. Nature 318: 439-445.

Johnson, D., J. Gautsch, J. Sportsman, and J.H. Elder. 1984. Im- proved technique utilizing non-fat dry milk for analysis of proteins and nucleic acids transferred to nitrocellulose. Gene Anal. Techn. 1: 3-8.

Kornberg, T., I. Siden, P. O'Farrell, and M. Simon. 1985. The engrailed locus of Drosophila: In situ localization of transcripts reveals compartment-specific expression. Cell 40: 45-53.

Krause, H.M. and W.J. Gehring. 1988. The location, modification, and function of the fushi tarazu protein during Drosophila embryogenesis. In Cellular factors in development and differentiation-Embryos, teratocarcinomas, and differentiated tissues (ed. S. Harris). Academic Press, New York (in press.)

Kuroiwa, A., E. Hafen, and W.J. Gehring. 1984. Cloning and transcriptional analysis of the segmentation gene fushi tarazu of Drosophila. Cell 37: 825-831.

Laughon, A. and M.P. Scott. 1984. Sequence of a Drosophila segmentation gene: Protein structure homology with DNAbinding proteins. Nature 310: 25-31.

Lawrence, P.A., P. Johnston, P. Macdonald, and G. Struhl. 1987. Borders of parasegments in Drosophila embryos are delimited by the fushi tarazu and even-skipped genes. Nature 328: 440-442.

Lee, W., P. Mitchell, and R. Tiian. 1987. Purified transcription factor AP-1 interacts with TPA-inducible enhancer elements. Cell 49: 741-752.

Maniatis, T., E.F. Fritsch, and J. Sambrook. 1982. Molecular cloning: A laboratory manual. Cold Spring Harbor Laboratory, Cold Spring Harbor, New York.

McGinnis, W., R.L. Garber, J. Wirz, A. Kuroiwa, and W.J. Gehring. 1984a. A homologous protein coding sequence in Drosophila homeotic genes and its conservation in other metazoans. Cell 38: 403-409.

McGinnis, W., M.S. Levine, E. Hafen, A. Kuroiwa, and W.J. Gehring. 1984b. A conserved DNA sequence in homoeotic genes of the Drosophila Antennapedia and Bithorax complexes. Nature 308: 428-433.

Meinhardt, H. 1986. Hierarchical inductions of cell states: A model for segmentation in Drosophila. J. Cell Sci. Suppl. 4: 2961-2969.

Meinhardt, H. and A. Gierer. 1980. Generation and regeneration of sequence structures during morphogenesis. J. Theor. Biol. 85: 429-450.

Mitchell, P.J., C. Wang, and R. Tjian. 1987. Positive and negative regulation of transcription in vitro: Enhancer-binding protein AP-2 is inhibited by SV40 T antigen. Cell 50: 847861.

Mitchison, T.J. and J.W. Sedat. 1983. Localization of antigenic determinants in whole Drosophila embryos. Dev. Biol. 99: $261-264$.

Mlodzik, M., A. Fjose, and W.J. Gehring. 1985. Isolation of caudal, a Drosophila homeobox-containing gene with maternal expression, whose transcripts form a concentration gradient at the pre-blastoderm stage. EMBO I. 4: 29612969.

Mott, J., R. Grant, Y.-S. Ho, and T. Platt. 1985. Maximizing gene expression from plasmid vectors containing the $\lambda P L$ promoter: Strategies for overproducing transcription termination factors. Proc. Natl. Acad. Sci. 82: 88-93.

O'Farrell, P.H. 1975. High resolution two-dimensional electrophoresis of proteins. J. Biol. Chem. 250: 4007-4021.

Ollo, R. and T. Maniatis. 1987. Drosophila Krüppel gene product produced in baculovirus expression system is a nuclear phosphoprotein that binds to DNA. Proc. Natl. Acad. Sci. 84: 5700-5704.

Ptashne, M. 1986. In A genetic switch, Cell Press and Blackwell 
Krause et al.

Science Publications, Palo Alto, California.

Rogers, S., R. Wells, and M. Rechsteiner. 1986. Amino acid sequences common to rapidly degraded proteins: The PEST hypothesis. Science 234: 364-368.

Rubin, G.M. and A.C. Spradling. 1982. Genetic transformation of Drosophila with transposable element vectors. Trends Genet. 1: 31-35.

Schneuwly, S., R. Klemenz, and W.J. Gehring. 1987. Redesigning the body plan of Drosophila by ectopic expression of the homeotic gene Antennapedia. Nature 325: 816-818.

Scott, M.P. and P.H. O'Farrell. 1986. Spatial programming of gene expression in early Drosophila embryogenesis. Annu. Rev. Cell Biol. 2: 49-80.

Scott, M.P. and A.J. Weiner. 1984. Structural relationships among genes that control development: Sequence homology between the Antennapedia, Ultrabithorax, and fushi tarazu loci of Drosophila. Proc. Natl. Acad. Sci. 81: 4115-4119.

Shepherd, J.C.W., W. McGinnis, A.E. Carasco, E.M. De Robertis, and W.J. Gehring. 1984. Fly and frog homeo domains show homology with yeast mating-type regulatory proteins. Nature 310: 70-71.

Struhl, G. 1985. Near-reciprocal phenotypes caused by inactivation or indiscriminate expression of the Drosophila segmentation gene ftz. Nature 318: 677-680.

Stüber, D., I. Ibrahimi, D. Cutler, B. Dobberstein, and H. Bujard. 1984. A novel in vitro transcription-translation system: Accurate and efficient synthesis of single proteins from cloned DNA sequences. EMBO I. 3: 3143-3148.

Studier, W.F. and B.A. Moffatt. 1986. Use of T-7 RNA polymerase to direct selective, high-level expression of cloned genes. J. Mol. Biol. 189: 113-130.

Towbin, H., T. Staehelin, J. Gordon. 1979. Electrophoretic transfer of proteins from polyacrylamide gels to nitrocellulose sheets: Procedure and some applications. Proc. Natl. Acad. Sci. 76: 4350-4354.

Wakimoto, B.T. and T.C. Kaufman. 1981. Analysis of larval segmentation in lethal genotypes associated with the Antennapedia gene complex in Drosophila melanogaster. Dev. Biol. 81: 51-64.

Wakimoto, B.T., F.R. Turner, and T.C. Kaufman. 1984. Defects in embryogenesis in mutants associated with the Antennapedia gene complex of Drosophila melanogaster. Dev. Biol. 102: $147-172$.

Weiner, A.J., M.P. Scott, and T.C. Kaufman. 1984. A molecular analysis of fushi tarazu, a gene in Drosophila melanogaster that encodes a product affecting embryonic segment number and cell fate. Cell 37: 843-851.

Weir, M.P. and T. Kornberg. 1985. Patterns of engrailed and fushi tarazu transcripts reveal novel intermediate stages in Drosophila segmentation. Nature 318: 433-445. 


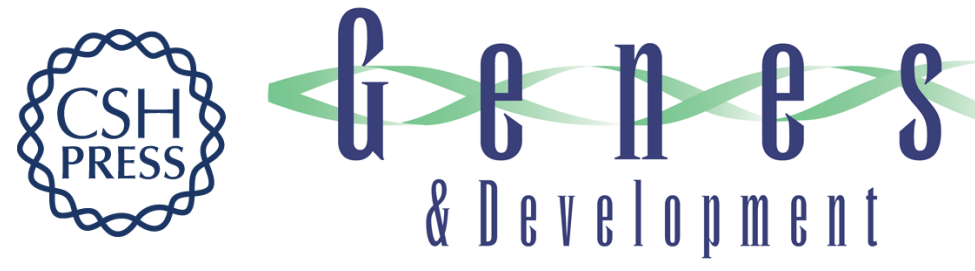

\section{Expression, modification, and localization of the fushi tarazu protein in Drosophila embryos.}

H M Krause, R Klemenz and W J Gehring

Genes Dev. 1988, 2:

Access the most recent version at doi:10.1101/gad.2.8.1021

References This article cites 49 articles, 8 of which can be accessed free at:

http://genesdev.cshlp.org/content/2/8/1021.full.html\#ref-list-1

License

Email Alerting

Service

Receive free email alerts when new articles cite this article - sign up in the box at the top right corner of the article or click here.

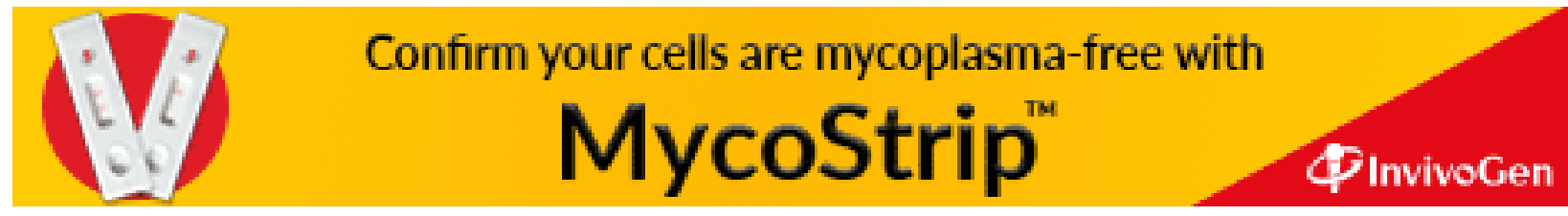

